\title{
Inside/Outside the Circle: From the Indochinese Designated Class to Contemporary Group Processing
}

\author{
ROBERT C. BATARSEH
}

\section{Abstract}

This article compares the conditions surrounding the creation of Canada's former Indochinese Designated Class and the contemporary group processing program. Under this program the UNHCR identifies and refers entire groupings of refugees for resettlement in Canada. The article also briefly touches on the selection of Tibetan refugees by Canadian officials in the late 1960 s and early 1970s. The Designated Class framework streamlined eligibility for resettlement and allowed government officials to respond to persons not covered by the narrower definition of refugee under the Convention. In a similar fashion, contemporary group processing aims to make resettlement processing efficient by skipping refugee status determinations and using group profiles. The aftermath of the Indochinese resettlement programs and the tightening of eligibility under the Indochinese Designated Class have shaped the creation of group processing. Concerns over "pull factors," economic migration, and fraud, along with the securitization of migration, have led to a preference for homogenous and self-contained groupings of refugees. The article traces the Canadian government's preoccupation with visualizing and drawing boundaries around groupings of refugees. While both group processing and the former Indochinese Designated Class aim to make resettlement processing efficient, this objective plays a more prominent role under the former, intersecting with security practices in unique ways and informing the selection of groupings of refugees.

\section{Résumé}

Cet article entreprend une comparaison des conditions influant sur la création de l'ancienne Catégorie désignée d'Indochinois du gouvernement canadien avec celles qui ont contribué au programme contemporain de traitement groupé de cas des réfugiés. Sous les auspices de ce programme, le HCR identifie et désigne des groupements entiers de réfugiés pour la réinstallation au Canada. L'article évoque également de façon brève le sélectionnement des réfugiés tibétains par des fonctionnaires canadiens durant la fin des années 60 et le début des années 70 . Le cadre des Catégories désignées avait simplifié le processus d'admissibilité pour la réinstallation et permis aux fonctionnaires du gouvernement de s'adresser aux personnes qui n'étaient pas couvertes par la définition plus étroite du statut de réfugié sous la Convention. De manière semblable, le traitement groupé contemporain de cas de réfugiés a pour objectif de rendre efficace le traitement des demandes de réinstallation en sautant l'étape de détermination de statut de réfugié et en se servant des profils groupés. L'article propose que les conséquences des programmes de réinstallation visant les Indochinois, ainsi que le renforcement des critères d'admissibilité dans le contexte de la Catégorie désignée d'Indochinois, ont influencé la création du traitement groupé de cas de réfugiés. Les préoccupations vis-à-vis des "facteurs d'attraction" pour les migrants, la migration économique, et la fraude, ainsi que la sécurisation de la migration, ont contribué à une préférence pour des groupements homogènes et bien délimités de réfugiés.

(C) Robert C. Batarseh, 2016. This open-access work is licensed under a Creative Commons Attribution-NonCommercial 4.0 International License, which permits use, reproduction and distribution in any medium for non-commercial purposes, provided the original author(s) are credited and the original publication in Refuge: Canada's Journal on Refugees is cited. 
L'article décrit la préoccupation du gouvernement canadien en matière de visualisation et de délimitation de groupements de réfugiés. Bien que le traitement groupé ainsi que l'ancienne Catégorie désignée d'Indochinois partagent le même objectif de rendre le traitement de la réinstallation plus efficace, cet objectif joue un rôle plus important dans le cas du premier, se croisant avec des pratiques de sécurisation d'une façon inédite et influant sur la sélection de groupements de réfugiés.

\section{Introduction}

T T istorically, states have grouped overseas refugees for resettlement, whether along the lines of nationality, ethnicity, race, labour skills, vulnerability, or political ideology. ${ }^{1}$ Depending on the context, sometimes this grouping is made explicit, whereas in others it is implicit in how the state responds to refugee movements, carving out groupings of refugees. This article focuses on those moments when the Canadian government has either explicitly developed frameworks for grouping refugees for resettlement or has reflected on this process. It charts changes in this process, from an emphasis on settlement potential with the Tibetans, to a desire to streamline eligibility under the Indochinese Designated Class, and finally to contemporary obsessions over fraud, security, and the boundaries of groupings of refugees under group processing. The initially open-ended designation of eligibility for the Indochinese is contrasted to the Canadian government's current preference for much tighter definitions of group membership under group processing. Concerns over "pull factors" and economic migration towards the end of the Indochinese resettlement program as well as UNHCR reforms in the late 1990 a and early 2000 s played an important role in shaping the development of group processing in 2003. In addition, the terrorist attacks of 11 September 2001 have increased the security concerns of resettlement states. In response, the UNHCR has strengthened registration and identification practices aimed at dealing with fraud. While both the former Indochinese Designated Class and group processing aim to make resettlement processing efficient, under the latter this objective plays a central role as the state prefers self-contained and homogenous groupings of refugees that are perceived as easy to process and not a threat to the Canadian population. I argue that contemporary preoccupations with boundaries, visibility, homogeneity, and efficiency under group processing provide the Canadian state with new variables of consideration in determining which grouping of refugees is the right fit for Canada.

The article draws on a mixture of archival research and interviews with key individuals familiar with Canada's group processing. While archival research provides useful insights into the development of the Indochinese Designated Class, the Tibetan resettlement program, and official group resettlement procedures, it reveals less about how group processing decisions are made. For this reason, 11 interviews were conducted with officials from Citizenship and Immigration Canada (CIC), ${ }^{2}$ the Canadian Department of Foreign Affairs (DFAIT), ${ }^{3}$ Canadian Border Services Agency (CBSA), the United Nations High Commission for Refugees (UNHCR), and the Canadian Council for Refugees (CCR). While the empirical focus of the article is on the historical and contemporary Canadian resettlement program, it also draws on the UNHCR's group resettlement methodology. Canada played a critical role in shaping the development of this method as well as the revitalization of resettlement within the UNHCR in the early 20oos. Additionally, the interviewing of UNHCR officials shed light on Canada's group processing program and the multilateral character of both the Bhutanese and Karen Burmese resettlement initiatives.

The article begins by briefly examining Canada's selection of Tibetan refugees in the late 1960s and early 1970s. It considers the UNHCR's and Dalai Lama's initial request to settle the Tibetans as a self-contained grouping, and the Canadian government's reluctance to do so. Despite this reluctance, concerns over the ability of the Tibetans to successfully settle in Canada shaped the government's assessment of them. Implicitly, it treated them as a grouping. The article then turns its attention to the initially positive response by Western countries to the plight of the Indochinese and the subsequent use of a loose definition of eligibility under Canada's Designated Classes to resettle them. I highlight how this regulatory framework aimed to work outside the Refugee Convention and streamline the determination of eligibility. The increasing skepticism towards the Indochinese resettlement programs in the buildup to the signing of the Comprehensive Plan of Action (CPA) in 1989 cast doubt on the openended definition of eligibility under the Designated Class. The perception of economic migrants and "pull factors" led to individual screening mechanisms to determine refugee status. The signing of the CPA coincided with the end of the Cold War, removing an important geopolitical motivation behind largescale resettlement to Western countries. During the 1990 os there was an emphasis on return, as resettlement became the least-preferred durable solution. Despite this move away from resettlement, the UNHCR in the latter part of the decade began to reform its resettlement operations. By the early 200os, resettlement states such as Canada began pushing the UNHCR to increase referrals. The creation of the group processing program in 2003 took place in a context where resettlement is officially based on protection 
needs and is targeted towards protracted refugee situations. This focus, however, is matched by state preoccupations with fraud and security risks. Under group processing, there is an emphasis in clearly visualizing and identifying homogenous and self-contained groupings of refugees. To demonstrate this, I draw on the program's pilot project in 2003 that selected groupings of Somali Madiban and Sudanese from the Dadaab refugee camp in Kenya. The article also considers the selection of the Bhutanese and the exclusion of Burundians, Rwandans, and Chechens from the program. I conclude by reflecting on the similarities and differences between group processing and the former Indochinese Designated Class. While earlier versions of the Indochinese Designated Class and contemporary group processing both aim to make resettlement processing efficient and place less emphasis on ensuring refugee status under the Convention, bureaucratic objectives are more pronounced under the latter, intersecting with security concerns in unique ways and informing the selection of groupings of refugees for resettlement.

\section{Tibetan Resettlement}

Following the annexation of Tibet by China in the 1950s, many Tibetans fled to India. ${ }^{4}$ Shortly afterward the Dalai Lama asked both Canada and Switzerland to accept Tibetan refugees. While Switzerland agreed, Canada declined. The former high commissioner to India, James George, noted that Immigration officials had concerns over the purportedly nomadic nature of the Tibetans, arguing that there was no immigration category for them..$^{5}$ George would become a key figure in Canada's eventual acceptance of the Tibetans, convincing former prime minister Pierre Elliot Trudeau to influence immigration officials to be more open to their resettlement. ${ }^{6}$ In 1966 the UNHCR attempted to persuade Canadian officials to settle the Tibetans as a "group," the hope being that this would help meet their spiritual and cultural needs.7 A year later an interdepartmental committee was formed to consider the plight of Tibetan refugees. While the committee ruled out the idea of group settlement as contrary to immigration policy, the government agreed to accept the Tibetans on an individual or family basis.

The initial apprehension of officials over nomads and the concept of group settlement reflected concerns at the time with the settlement potential of refugees. The decision against group settlement was based on the perception that it "would hinder the permanent integration of the Tibetans into the life of the country."9 A report in 1975 by the Department of Manpower and Immigration that reviewed the Canadian resettlement program for the Tibetans highlights how immigration officials preferred refugees from towns (or settled regions of Tibetans) with some form of secondary education. Officials also felt that younger married couples with small families and single workers would be easier to integrate. In contrast, there was a belief that older refugees and those from unsettled rural areas would have trouble finding employment, be difficult to train or retrain, and slow to learn one of Canada's official languages. ${ }^{10}$ After a review of the Swiss experience with Tibetans, the interdepartmental committee in the late 196os concluded, "Amongst the nomads the process of adaptation has been much more difficult. The nomads cling to the communal households that were set up to receive them. They are more dependent on official help and experience greater insecurity. Moreover they have a tendency to isolate themselves from Tibetans from other walks of life."11 Not surprisingly, Canadian officials selected only two nomads from Tibet. ${ }^{12}$

While the government refused to formally recognize the concept of group settlement with the Tibetans, it implicitly treated them as a grouping, assessing their education, skills levels, and ability to adapt to Canadian life. Under much different circumstances, group processing calls for the selection of self-contained groupings of refugees. In part, there is now a belief that this facilitates the integration of refugees. ${ }^{13}$ More important, the desire for self-contained and finite groupings reflects important changes in the rationale of how states approach resettlement. Understanding these changes requires consideration of the lasting influence of the Indochinese refugee movement and the eventual reform of the Designated Classes.

\section{Big Circles: The Indochinese Refugee Movement and the Evolution of the Designated Classes}

The daily media images of the plight of the Indochinese refugees in the 1970s captured the general public's attention in Western states. And while Cold War ideological and geopolitical considerations guided Canada's positive response to the Indochinese, ${ }^{14}$ so did humanitarian considerations. The international community's selection of over 350,000 Vietnamese and Laotian refugees, as well as half a million Cambodians, formalized a system of first asylum in the region for permanent resettlement elsewhere, also known as "an open shore for an open door."15 The Canadian government resettled the Indochinese under the newly created Designated Classes system, following the passing of the 1976 Immigration Act. This simplified the question of eligibility for resettlement by skipping refugee status determinations based on the Convention and focusing instead on admissibility. ${ }^{16}$ Commenting on the Indochinese Designated Class, Raphael Girard explains, "Given that none of the boat people in South East Asia were going to return to Vietnam and they could not stay any length of time in the countries of first asylum, the issue of the Convention status of the 
individuals was not crucial to their need for resettlement. This greatly enhanced the efficiency of our selection activities in the field."17

An important objective of the Designated Class framework was to allow the Canadian government to respond to individuals in need of protection beyond the rather narrow definition of a refugee in the Convention. ${ }^{18}$ Under the Convention, and the text of the 1967 Protocol Relating to the Status of Refugees, a refugee is "a person who is outside his or her country of nationality or habitual residence; has a well-founded fear of being persecuted because of his or her race, religion, nationality, membership of a particular social group or political opinion; and is unable or unwilling to avail him- or herself of the protection of that country, or to return there, for fear of persecution." ${ }^{19}$

Tanya Basok and Alan Simmons explain that the Designated Classes framework "gave authority to the Governor-in-Council to designate a group of people who do not qualify for Convention refugee status but who are, nevertheless, threatened by political, social or religious upheavals. ${ }^{20}$ Commenting on the framework, Michael C. Lanphier points to how determinations of eligibility for resettlement could be moulded to "fit the characteristics of the particular group of displaced or persecuted persons." ${ }^{21}$ He goes on to say that "the existence of the definition of three different 'Designated Classes': Indochinese, Latin American, and SelfExile (East European), each with differing specifications, indicates a distinctly innovative and flexible governmental approach in determining eligibility for selection under relaxed refugee admissibility criteria." ${ }^{22}$

It is important to note that this was not the first time that the Canadian government developed refugee policies outside the framework of the Refugee Convention. Gerald Dirks explains that one reason the Canadian government was initially hesitant to become a signatory to the Convention in 1951 was the fear that it would lose the ability to deport or exclude refugees on national security grounds. In particular, authorities were concerned about Soviet espionage and subversion. ${ }^{23}$ Cold War politics guided Canada's selection of refugees during this period, an important example being its positive response to the plight of the Hungarians in $1956-7 .{ }^{24}$ In 1969 Canada ratified the Refugee Convention and Protocol. That same year it set up a special program for Ugandan Asians. Girard notes the selection of Ugandan Asians was not affected by Canada's signing to the Convention, since, "while no one had any doubt that these victims of racial hatred were refugees, in fact most could not meet the Convention definition because they were still in their country of citizenship or usual residence." 25 Girard goes on to say that whether or not the Ugandan Asians were refugees was academic, "since Idi Amin himself had defined the eligible group based on their ethnicity."26 The statements highlight how the grouping of refugees can simultaneously be inclusive and exclusive. On the one hand, the Ugandan Asians were excluded for their imputed membership in an ethnic grouping. On the other hand, this made it easier for the Canadian state to determine eligibility for resettlement.

During this same period, the Canadian government attempted to redirect the refugee program away from its focus on European refugees towards the selection of nonEuropeans. As part of this move the federal Cabinet proposed the creation of an "oppressed minority policy," which would allow the government to respond to groupings of refugees that were of interest to authorities but did not fall under the Refugee Convention definition, specifically the requirement to be outside one's country of citizenship or habitual residence. ${ }^{27}$ For different reasons then, throughout the post-Second World War period, the Canadian government has worked outside the formal framework of the Refugee Convention in its response to refugee movements. The "Designated Classes" were a continuation of this practice.

The sheer size of the Indochinese crisis and the visible urgency of the situation played a role in adopting a relatively open-ended definition of eligibility under the Designated Class framework. Canada considered Vietnamese along with Laotians, Cambodians, and Hmong who fled their countries of origin after 30 April 1975 to be ipso facto refugees. ${ }^{28}$ This amounts to a prima facie status that has historically been used in situations of large-scale displacement. ${ }^{29}$ Under this designation, each member is regarded prima facie as a refugee in the absence of evidence to the contrary. In fact, in 1984 some within the Immigration Department felt that the Indochinese Designated Class definition of eligibility was too narrow and was preventing the inclusion of individuals who had received permission to temporarily remain in countries signatory to the Refugee Convention but intended to resettle to Canada. ${ }^{30}$ Officials aimed to loosen eligibility so as to include more Indochinese.

\section{The Circle Is Getting Too Big}

As the crisis in Southeast Asia wore on, resettlement states increasingly viewed the movement of Indochinese refugees as motivated more by economic considerations than a genuine concern with safety. ${ }^{31} \mathrm{~A}$ position paper from the Indochinese Consultative Group Meeting in Ottawa in April 1988 in the lead up to signing of the Comprehensive Plan of Action ( $\mathrm{CPA}$ ) suggests that resettlement was "initially the most immediate and simplest response to relieving the burden of first asylum countries. Now it is part of the problem identified with the continued outflow as many persons are seeking resettlement for economic or family reasons rather than in response to individual persecution. To maintain 
first asylum commitment throughout the region, resettlement must remain part of the international response but not to the exclusion of encouraging other activities designed to deter the outflow."32

Those "other activities" were the introduction of regional refugee status determination mechanisms and the encouragement of what was at first voluntary but later on involun tary repatriation under the CPA signed in 1989. This ended the use of "blanket resettlement" 33 and the prima facie designation. ${ }^{34}$ As Sten Bronee explains, “The establishment of a procedure for determining refugee status brought an end to automatic resettlement." 35

The CPA worked by using specific cut-off dates. Late arrivals to countries of first asylum in Southeast Asia would be subjected to refugee status screening mechanisms while the "long-stayers" who had been present in these countries up to these cut-off dates would continue to be automatically eligible for resettlement. An important issue for Canadian officials was to bring the Indochinese Designated Classes in line with the CPA. There was recognition that the definition of eligibility under this system was inconsistent with the introduction of screening mechanisms under the CPA. At a preparatory meeting of the International Conference on Indochinese Refugees in Kuala Lumpur in March 1989, the Canadian High Commission noted that Canada has the weakest legislative basis for dealing with the issue of non-eligible individuals. ${ }^{36}$ At that same meeting, Vietnam proposed using the Organization of African Union (OAU) definition of a refugee for screening purposes; however, the Canadian High Commission noted that this definition "is as broad as our Designated Class Regulations and Canada should not support inclusion [of it]." 37 A month later, a letter to the minister of employment and immigration from the associate deputy minister/vice-chairman explains to the minister that, in light of the CPA's focus on Convention refugees, the "designated class regulations will eventually have to be reviewed, since their continued use would be both next to impossible in practical terms, and contradictory to the spirit of the common approach developed through the ICIR process." ${ }^{38}$

The Indochinese Designated Class regulations were eventually reformed so that eligibility was restricted to Vietnamese and Laotian "long-stayers" and "screened-in" recent Vietnamese and Laotian arrivals found to be Convention refugees. ${ }^{39}$ However, all Cambodians (both long-stayers and recent arrivals) would continue to be eligible under the regulations. $4^{\circ}$ Part of the government's communication strategy was to emphasize that "these changes will help us concentrate our efforts on the 'long stayer' population in refugee camps through Southeast Asia." 41 There was a belief by some officials that the plight of the "long-stayers" would likely receive "considerable attention from the media and from interested groups in Canada." 42

Tightening eligibility under the Designated Class included closing a possible loophole for Indochinese guestworkers working in Eastern Europe. An internal government memo explains that under the revised Designated Classes the wording may allow Vietnamese, Laotian, and Cambodian guest workers in Eastern Europe to apply for benefits. The document explains that "the guestworkers left their countries of origin legally in order to work abroad. There should be no impediment to their return to Vietnam, Laos and Cambodia. In order to prevent large numbers of guestworkers from qualifying under these Regulations it is imperative the changes be made as soon as possible."43

The closing of this loophole contrasts with the decision in 1984 that sought to expand eligibility to individuals seeking temporary protection in countries that were signatories to the Convention prior to resettling in Canada. Such was the nature of the Designated Classes, which could be reformed to meet changing circumstances and political preferences.

While the CPA certainly did not end large-scale resettlement, its introduction of screening mechanisms, measures to deter clandestine departures from countries of origin, and consideration of involuntary repatriation (the most contentious aspect of the agreement) ${ }^{44}$ reflected officials' belief that many of the remaining Indochinese were no longer genuine refugees in need of resettlement. Moreover, resettlement was increasingly viewed as a "pull factor" linked to overly broad (or loose) definitions of eligibility under systems such as Canada's Designated Classes. This can be seen in the UNHCR's reflection on the response to the Indochinese refugee crisis in its 2011 resettlement handbook: "After the CPA, the use of large-scale resettlement as a solution waned. In retrospect, the decision in 1979 to adopt blanket resettlement was seen as a major 'pull-factor' causing very large numbers of people to leave Vietnam primarily for economic and social reasons, rather than to seek protection. Meanwhile, elsewhere in the world, refugees in desperate need of resettlement suffered from lack of available places." 45

At the same time, there was a feeling by some officials that since Canada was increasingly becoming a country of first asylum it would have to scale back its resettlement numbers. At the Indochinese Consultative Group Meeting in Ottawa in April 1988 this concern was linked to the associated backlog of refugee claimants in Canada and calls to end open-ended resettlement commitments. ${ }^{46}$

The CPA also coincided with the end of the Cold War. For most of this period states relied on what Alexander Aleinikoff calls the exilic approach in dealing with the issue of forced displacement. This approach emphasized thirdcountry resettlement over the return of refugees to their 
country of origin. Both Aleinikoff and B. S. Chimni chart its decline as beginning in the mid-1970s and taking hold in the 1980 os. ${ }^{47}$ For Chimni, the move away from resettlement towards an emphasis on first voluntary and then later forced repatriation reflected the interests of dominant states. From their perspective, the absence of labour shortages no longer warranted large-scale resettlement. ${ }^{4}$ In addition, the end of the Cold War removed the political value in resettling large numbers of refugees fleeing communist regimes. ${ }^{49}$ In explaining the emphasis on the right of return in the 1990s, Aleinikoff notes, "From a liberal, human rights approach, the fundamental wrong done to refugees was a denial of their right to live freely in their home countries. Furthermore, forced exile violated the internationally recognized right of citizens to return to their countries of origin. From this perspective, resettlement can never be the primary remedy because it does not restore the right; rather, the 'basic solution' must solve the problem of the denial of freedoms attending exile, either by preventing the conditions that compel flight or remedying those conditions after flight."50

Aleinikoff argues that, given the entrenched practices of non-intervention into the affairs of a sovereign state, it is unlikely that developed states would attempt to rectify the human rights situations in countries of origin. For this reason, he suggests that the exilic bias is being exchanged for "policies of containment-detention of asylum seekers, visa requirements, closing opportunities for resettlement, pushbacks, and return. These policies are grounded less in a desire to breach the walls of state sovereignty than an attempt to keep Third World refugee problems from inconveniencing the developed states."51

In a similar vein, Jennifer Hyndman points to "efforts to assist refugees closer to their homes in 'regions of origin.' This occurred first in the early 1990s through a policy of 'preventative protection' and then in the 2ooos through the externalization of asylum." 52

These external pressures influenced the UNHCR as resettlement became the least-preferred durable solution in the 1990s. 53 The organization came to view it as a protection tool targeted towards individuals and families who had become vulnerable in their country of asylum and therefore needed resettlement. ${ }^{54}$ Within the UNHCR there was a perception by some that resettlement was motivated by geopolitical considerations, as opposed to a genuine concern for refugee protection. 55

Despite the pressures against resettlement during this period there was some movement within the UNHCR in the latter half of the 1990s to once again raise its profile as a viable durable solution. Kristin Bergtora Sandvik points to the development of a comprehensive resettlement handbook, beginning in 1997, that set clear standards for referring refugees for resettlement. ${ }^{56}$ The organization aimed to emphasize rationality and transparency in its resettlement process in a bid to strengthen its credibility and broaden the confidence of resettlement states, refugees, and other partners. ${ }^{57}$ Sandvik explains that the idea behind the 2004 version of the handbook "was that by constructing a rigorous procedure of individual selection, within the confines of asylum and host country quotas, only 'deserving refugees' truly in need of protection would be found eligible for resettlement." ${ }^{58}$ The reforms stemmed from a perception within the UNHCR that its previous approach to resettlement was unorganized, ad hoc, prone to fraud, and disconnected from a broader analysis of protection situations involving refugees. ${ }^{59}$ A serious corruption scandal in Nairobi in 1999-2000 that involved UNHCR staff members in the selling of resettlement spaces also contributed to the reforms in which "integrity is now a major theme of UNHCR's resettlement program." 60

By the early 2000 s there emerged a renewed belief in the usefulness of resettlement as a potential durable solution.61 It is reflected in the passing of the UNHCR Agenda for Protection (2003) and Convention Plus initiatives (2004), ${ }^{62}$ which called for the expanded use of resettlement as a durable solution, particularly for groupings of refugees. ${ }^{63}$ These broad initiatives led to the signing of the UNHCR Multilateral Framework of Understanding on Resettlement, ${ }^{64}$ which emphasized multilateral resettlement efforts focused on "protracted refugee situations" and the "strategic use of resettlement." 65 Officially, the strategic use of resettlement attempts to create benefits that extend beyond the refugees being resettled, including strengthening the protection environment in the country of asylum, decongesting camps, and opening up other durable solutions such as local integration. ${ }^{66}$ The idea is to utilize resettlement in tandem with other durable solutions as part of a comprehensive approach to dealing with protracted refugee situations.

The Canadian government played an important role in these efforts during this period. Shauna Labman explains that "as co-chair of the resettlement strand of Convention Plus, Canada led the authorship of the MFU [Multilateral Framework of Understanding on Resettlement]." ${ }^{67}$ In June 2003, at a forum that discussed resettlement, the Canadian delegation tabled a discussion paper titled "Resettlement and Convention Plus Initiatives." According to Joanne Van Selm, this paper had been developed in the Working Group on Resettlement under Canadian chairmanship. This is a forum for the UNHCR and resettlement states to discuss priorities and needs in the area of resettlement. A UNHCR official noted that during this period the Canadian government was a very active chair of the Working Group on Resettlement. ${ }^{68}$ Based largely on the Canadian resettlement program, the 
discussion paper suggested that resettlement "can be a timely and cost effective durable solution." ${ }^{69}$ Van Selm explains that the paper called for "protection-based criteria that go beyond the 1951 Convention [that] would help to make resettlement a more flexible tool."7o As noted earlier, there is a long history in Canada of developing policies that determine eligibility outside the Refugee Convention framework. The emphasis on protection-based criteria is reflected in the passing of the 2002 Immigration and Refugee Protection Act (IRPA) in Canada, which signalled a move towards a more liberal and non-discriminatory refugee system.

Part of the revitalization of resettlement during this period also stemmed from the fact that states approached the UNHCR about increasing the referrals of refugees for resettlement. The organization responded by revamping and strengthening its referral methodologies in a bid to proactively identify all refugees in need of resettlement globally as opposed to field officers being selective about referrals. ${ }^{71}$

As the discussion above demonstrates, the Canadian government played a central role in the early 2000 in renewing resettlement. However, the emphasis on vulnerability, flexibility surrounding the Convention definition of a refugee, and responding to protracted situations is only part of the story. Equally important are heightened concerns by states over security and fraud. A UNHCR official recalls that, in the aftermath of the 9/11 terrorist attacks, the organization was forced to respond to these concerns by reinforcing identity and registration practices. ${ }^{72}$ At the same time, while the passing of IRPA in 2002 emphasized refugee protection, as Anna Pratt notes, it also ushered in a whole range of inadmissible classes based on forward-looking risk-management techniques. $^{73}$ In a similar vein, anticipating the effects of the passing of IRPA, Casasola argued that while "ability to establish" is a decreasing problem with Canada's resettlement program, medical and security restrictions are likely to be the new obsessions. ${ }^{74}$

The character of contemporary resettlement differs from earlier largescale programs such as the Indochinese. Despite efforts to revitalize it, lasting concerns over "pull factors," combined with obsessions over fraud and security, have led to a much more limited and targeted role of resettlement. In the context of the strategic use of resettlement, these changes resonate with Mariana Valverde and Michael S. Mopas's concept of "targeted governance" and its associated reliance on risk-management techniques informed by a neoliberal rationality. ${ }^{75}$ This rationality is reflected in the drive in group processing to make resettlement processing efficient. In part, this is achieved by using shortened UNHCR resettlement registration forms (RRFS), skipping refugee status determinations (the acceptance of prima facie basis), and implementing group profiles. In this respect, group processing is similar to early versions of the Indochinese Designated Class, as both work outside the Convention and simplify the question of eligibility for resettlement. However, it differs from later versions of the Indochinese Designated Class in that it is less concerned with ensuring refugee status under the Convention than with developing clear criteria for membership in chosen groupings. Moreover, bureaucratic objectives intersect with security concerns and inform the selection of specific types of groupings of refugees viewed as ideal for efficient forms of overseas processing.

The desire for finite and homogenous groupings of refugees can be seen in the initial discussions among the IOM, UNHCR, and Canadian Immigration authorities during the group processing pilot project in 2003. The UNHCR had approached the Canadian government about resettling two groupings of refugees out of the Dadaab refugee complex in Kenya. The first was what was understood as a "distinct" group of Somali Madiban and the second was a group of Sudanese refugees. The UNHCR had determined that members of each grouping had similar refugee claims. As a result, Canada was willing to use the prima facie designation for them..$^{7}$ However, authorities insisted that the UNHCR have safeguards in the process in order to ensure there were no "imposters as part of the groups." ${ }^{77}$ A CBSA official emphasized the importance of being able to establish identity and to confirm that individuals are genuinely members of the groupings. State officials worked with UNHCR and IOM staff to verify membership in the chosen groupings. The CBSA set up guidelines of the screening process, defined the chosen groupings (i.e. who's included), and contracted the IOM to do the initial pre-screening. The same сBsA official describes the discussions that occurred between CIC and the IOM: "What we said to the IOM is, "We want you to work with the UNHCR, and what we want you to do is to define and encapsulate this group. And once you have done that, nobody can be added afterwards and nobody can leave the group, as long as they are content to be a part of that group."'78

Demonstrating the unease that Canadian officials sometimes have with group resettlement, the same official exclaimed, "It's not just identifying the individuals. It's identifying the individual within the context of the group. Refugees are no different than anyone else. If they can inject themselves into a group, they will do that, just because they are desperate enough to get out." ${ }^{79}$

While the IOM and UNHCR conduct numerous identification and verification exercises under group processing, from the perspective of Canada's security agencies, the organization lacks the intelligence to back these assessments. The same CBSA official quoted above refers to the UNHCR's screening practices as being based on "face value." In contrast, the CBSA purportedly has significant intelligence on 
terrorist organizations and groups. ${ }^{80}$ For this reason, Canadian officials reverified the identities of the chosen Somali Madiban and Sudanese groupings and then compared them with the initial UNHCR list of members of both groups. This became the standard practice for Canada's group-processing program and was applied to both the Karen and Bhutanese refugee groups.

While the Bhutanese was a much larger grouping of refugees compared to the Somali Madiban and Sudanese, discussions in both the Core Group on the Bhutanese (CGB) and the more routine Working Group on Resettlement (WGR) led to the belief that this refugee population was sufficiently encapsulated, given the particular location of the camps that house them in Nepal. This in turn minimized the potential for "pull factors" and the infiltration of what were perceived as unwanted elements into the camps. The same CBSA official remarked that because Nepal was not contiguous with Bhutan, "it was a pretty encapsulated population, it was a big population, but it was essentially defined." ${ }^{81}$ In addition, CBSA and CSIS assessments had determined that the Bhutanese were not a security risk to Canada. In fact, one official referred to them as a "clean population." 82

In contrast to these chosen groupings of refugees, some are deemed problematic and are therefore excluded from the program. From the perspective of some within the Canadian security establishment, the current situation in the Dadaab refugee camp in Kenya is no longer ideal for group processing, for several reasons. First, there is a concern that this refugee population contains "threatening" elements, specifically members of the listed terrorist organization Al Shabaab. An immigration official explained, "Bottom line, we cannot claim that the entire Somali population is problem-free." 83 Second, according to this same official, the mixed nature of the refugee population in Dadaab (some are fleeing famine as opposed to persecution under the Convention) makes the current Somali refugee population in Dadaab an unlikely candidate for Canada's group processing. ${ }^{84}$ Similar concerns were found with Burundians and Rwandans, what one official referred to as the "genocide populations." The same official explains, "If we had a really problematic population (and we have had problematic populations in Africa), it's particularly people that were involved in genocide in Rwanda and Burundi. We can't touch those populations. Those are very difficult, and as a group they are more problematic than they are worth our time to try and go in and screen out the good from the bad, because there was so many of them involved at various times with respect to genocide." ${ }^{\text {85 }}$

Under group processing, heterogeneous groupings of refugees with "risky" elements are excluded, as the Canadian government wishes to avoid separating "risky" from "at-risk" individuals. Such practices are viewed as running counter to the bureaucratic objectives of the program to streamline the overseas processing of groupings of refugees. Several officials used the expression "generate efficiencies" in describing this objective of group processing. ${ }^{86}$

The drive for efficiency has led to attempts by officials to anticipate whether or not group processing candidates would require lengthy security assessments. A Canadian Immigration official's remarks on CIC's reliance on the CBSA for security screening under group processing demonstrate this concern:

We only go to CBSA once we have figured that this is a population that we might be interested in, that we actually could have the capacity, the resources that we could get to them. We ask them, "Is there a real reason why we shouldn't [chose them]? Do they have flags?" If they tell us that 30 per cent of that population you are going to have to send for an in-depth clearance process, much more scrutiny, where there is a csis interview, then obviously we are not going to get any savings there, no efficiencies to be generated. People would be sitting in limbo waiting for clearance. ${ }^{87}$

An example of this occurred when Canadian officials rejected Chechens for group processing. According to the same official, "As a general rule, we've told the UNHCR, 'Don't bother referring us groups of Chechens.' The number that have been engaged in other activities, it's like every one of them would have to go through a thorough screening, the odd individual woman maybe. 'But don't come to us and say, "Would you take 500 Chechens?," because we know that all 500 we would have to really scrutinize."'88

Rather than expend the resources necessary to sort the "risky" from the "at-risk," the state avoids groupings of refugees deemed potentially "risky." Part of this process involves the examination of what the CBSA calls the "inadmissibility patterns" of refugee populations. A CBSA official explained that, on the basis of these examinations, the security agency would determine if refugee groups were good candidates for resettlement. ${ }^{89}$ This suggests that with group processing, security screening involves not only the comparison and contrasting of different groupings of refugees, but also the same grouping across different time periods. Risk-management techniques take on spatial and temporal dimensions. The "inadmissibility patterns" of earlier asylum claimants and resettlement applications from a refugee population play a role in determining the viability of offering resettlement to current refugees from the same population. The relation between the drive for efficiency and security practices under group processing has led to novel variables of consideration in determining the ideal grouping of refugees for resettlement. 
A key document used in group resettlement schemes such as group processing is the UNHCR's Group Profile and Proposal Document (GPPD). As noted earlier, GPPDs, or group profiles, permit the use of either shortened Resettlement Registration Forms (RRFS) for chosen members of a grouping or, in the case of the United States Priority $2^{90}$ referral, the direct transmission of basic bio data without RRFs. ${ }^{91}$ Among the things included in this profile are gender breakdown of the refugee population, ethnic, religious, occupational and social background, exclusion concerns, durable solutions analysis, quality of registration, need for resettlement, and possibilities for "pull factors." The GPPD also considers how homogenous groupings of refugees are in common causes of flight, or narratives of persecution and the grouping's distinctiveness relative to the wider refugee population in refugee camps.92 Commenting on the makeup of the GPPD, Martin explains, "The objective is to identify 'finite groups' that can become the focus of resettlement efforts. Such clarity about the group's dimensions is important, both to guard against fraud and to minimize any magnet effect generated by the resettlement activity. This theme was repeated to me many times during my interviews." 93

Martin points to how the group methodology reflects how to overcome opposition to resettlement by some within the UNHCR ranks, on the basis of concerns over new "pull factors." ${ }^{94}$

These concerns are reflected in the statements of a UNHCR official who explained that resettlement countries like to draw a circle around the grouping in order to know who's in it and who's not. ${ }^{95}$ The same official said, "It's like if you had perfect vision at the moment, you would know all the people that are in that group... To give you an example, one of the group definitions would be like Eritreans of Kunama ethnicity who are in the Shemelba camp who are registered between this date and that date, so in theory, even if you don't have all those names right in front of you right then, it's a finite group." 96

The notions of "perfect vision" and "drawing circles" capture the active role that states play in crafting homogenous and self-contained groupings of refugees. This is to be achieved through multiple verification and re-verification exercises and the proactive production and analysis of group profiles. The need for such clarity of group membership differs from the earlier definitions of eligibility under the Indochinese Designated Class in which individual Vietnamese, Cambodians, and Laotians were eligible for resettlement to Canada if they could demonstrate that they left their respective countries of origin after 30 April 1975.

As noted earlier, group processing was created in a context in which states and the UNHCR sought to revitalize resettlement. In part, this move was in response to increased concerns over protracted refugee situations, or what was known in the early 2000 s as refugee warehousing. Under the strategic use of resettlement, the selection of large groupings of refugees with similar protection needs is viewed as one solution in resolving these situations. ${ }^{97}$ At the same time, the desire for "perfect vision" and "drawing circles" attempts to capitalize on the immobility of refugees caught in prolonged displacement. The perceived distinction between the heterogeneous nature of refugees in urban centres, compared to the homogeneity and immobility of camp refugees, is captured by one UNHCR official:

In a camp situation you have a group of people who are very homogenous, because they belong to the same ethnic group, they came out of the same protection situation ... so you have ... a population which is very homogenous, in terms of not only their profile, they are all the same country, same nationality, the same ethnic group, the same language, the same everything ... unlike in an urban context where you have a mixed bag of cases [in] which you have a refugee from Iran, who escaped because of religious persecution, a refugee from another country who escaped because of political activities. $9^{8}$

When there are limited resettlement spaces, the decision to focus group resettlement efforts only on refugee camps has serious consequences for the millions of refugees living in urban centres. Moreover, even within the space of refugee camps, the desire for "perfect vision" and "drawing circles" is confronted with fluid situations. Hyndman's analysis of "ordering disorder" in Kenyan refugee camps points to the standardization efforts of the UNHCR that fail to account "for local historical contexts" and to refugees who resist technologies of knowing, such as headcounts. 99

The preference of resettlement states for groupings of refugees with common narratives of flight and persecution has created tensions with the UNHCR's system for determining resettlement need. States prefer to group refugees according to similar ethnicity, location, experiences of violence, or flight, while the UNHCR bases decisions on the need for resettlement in countries of first asylum. ${ }^{100}$ Given state concerns over security and fraud, as well as the UNHCR's reliance on donors, it is difficult to envision the organization challenging states on this matter. As the UNHCR has attempted to reassert the legitimacy of its resettlement operations, it has developed mechanisms to mitigate fraud and deal with potential "pull factors" in programs such as its group methodology.

\section{Conclusion}

Throughout the post-Second World War period the Canadian government has developed different frameworks for 
grouping refugees. In many cases these worked outside the formal definition of a refugee under the Convention. While the government refused group settlement with the Tibetans, it treated them as a grouping in other ways, separating those perceived as easy to integrate and those deemed difficult. A different set of priorities was behind the creation of the Designated Classes. With the Indochinese, the concern was to make resettlement more efficient by streamlining eligibility and having the flexibility to work outside the narrow framework of the Refugee Convention. At the beginning of the Indochinese crisis, a mix of Cold War politics and humanitarian concerns supported a broad definition of eligibility for resettlement. As the crisis wore on, however, and circumstances changed, the government sought to tighten this eligibility.

The conditions surrounding the creation of group processing differ and yet were influenced by the aftermath of the Indochinese resettlement programs. Similar to earlier versions of the Indochinese Designated Class, there is less concern with ensuring refugee status based on the Convention; the state accepts the prima facie designation. This gives the Canadian government the flexibility to select groupings of refugees it desires, regardless of whether or not members of these groupings fit the narrow definition of a refugee under the Convention. However, concerns over fraud, security risks, and "pull factors" have led officials to obsess over clear criteria for membership in groupings of refugees selected for resettlement. The state is preoccupied with visualizing and drawing boundaries around groupings of refugees. Moreover, the emphasis on creating efficiencies is much more pronounced, compared to the former Indochinese Designated Class. While the Canadian government reformed definitions of eligibility under later versions of Indochinese Designated Class in response to concerns over "pull factors" and economic migrants, under group processing it avoids risky, fluid, and heterogeneous groupings of refugees. The relations between the neoliberal drive for efficiency, security practices, and the desire for homogeneity under group processing point to new variables of consideration in the Canadian state's assessment of the ideal grouping of refugees for resettlement.

\section{Notes}

1 Before proceeding, a note on terminology is in order. In what follows, the use of the term group is not taken for granted, but rather is based on considerable reflection over how to articulate the group processing process in a manner that does not presuppose the existence of "groups" of refugees. Consider, for example, the formal definitions of the terms grouping and group. According to the Merriam-Webster Dictionary, a group is defined as "a number of individuals assembled together or having some unifying relationship," whereas grouping is "the act or process of combining people or things into groups." The former assumes individuals with pre-existing commonalities (i.e. "groups"), whereas the latter emphasizes the active process through which "groups" are formed in the first place. The very label group resettlement program presupposes the groupness of those whom authorities aim to resettle. In contrast, this article examines the ways in which resettlement selection practices play a role in producing and reproducing "groups." I will refrain from using the term group because I do not want to reinforce the sense that "groups" are there for resettlement schemes to discover. I want to get at how governments do not just choose between pre-existing "groups," but the processes that they use to choose also construct them at the same time.

2 Changed to Immigration, Refugees, and Citizenship Canada under the Liberal government.

3 Changed to Global Affairs Canada under the Liberal government.

4 Valerie Knowles, Strangers at Our Gates: Canadian Immigration and Immigration Policy, 1540-2007 (Toronto: Dundurn Group, 2007), 212; Gerald E. Dirks, Canada's Refugee Policy: Indifference or Opportunism? (Montreal and Kingston: McGill-Queen's University Press, 1977), 235.

5 James George, former high commissioner to India, interviewed in Sandro Contenta, "For Tibetan Refugees, Canada Was Literally the New World," Toronto Star, 23 October 2010, http://www.thestar.com/news/world/2010/10/23/ for_tibetan_refugees_canada_was_literally_the_new_ world.html.

6 Ibid.

7 Jan Raska. "Tibetan Immigration to Canada," Canadian Museum of Immigration at Pier 21, https://www.pier21.ca/ blog/jan-raska/tibetan-immigration-to-canada.

8 W. Smith, Tibetan Refugees: A Second Life in a New Land (Ottawa: Research Projects Group, Strategic Planning and Research, Department of Manpower and Immigration, 1975). See also memorandum to Cabinet, "The Settlement of a Limited Number of Tibetan Refugee Families in Small Family Groups in Canada," 30 April 1970, Cabinet no. 611/70, Library and Archives Canada. Under the section entitled Factors, it states, "In December 1968, the Prime Minister advised the Dalai Lama that every possible avenue for the movement and settlement of Tibetan refugees as a group had been explored and the conclusion had been reached that settlement as a self-contained group would not be practicable. The Prime Minister said, however, that the migration of Tibetans on an individual or family basis would be acceptable and viewed sympathetically. The Dalai Lama was asked to indicate whether individuals or families would be interested in coming forward on this basis. If so, he was informed that we would 
be prepared to explore further the possibility of an initial experiment. The approach suggested was accepted by the Dalai Lama in a letter dated January $8,1969 . "$

9 Smith, Tibetan Refugees.

10 Ibid.

11 Ibid.

12 Ibid.

13 CIC, Media Lines/Qs and As, Karen Refugee Group Processing Exercise, 26 May 2006, 3.

14 See Reg Whitaker, Double Standards: The Secret History of Canadian Immigration (Toronto: Lester and Orpen Denys, 1987).

15 Courtland W. Robinson, "The Comprehensive Plan of Action for Indochinese Refugees, 1989-1997: Sharing the Burden and Passing the Buck," Journal of Refugee Studies 17, no. 3 (2004): 320.

16 Raphael Girard, "Designated Classes: A Regulatory Device to Target Humanitarian Resettlement Programs," Canadian Immigration Historical Society, Bulletin 45, January 2005, http://cihs-shic.ca/2005/01/designated-classes/

17 Ibid.

18 Tanya Basok and Alan Simmons, "A Review of the Politics of Canadian Refugee Selection," in The International Refugee Crisis: British and Canadian Responses, ed. Vaughan Robinson (Oxford: Houndmills, Basingstoke, Hampshire: Macmillan / Refugee Studies Programme, University of Oxford, 1993), 133, 148; Michael C. Lanphier, "Canada's Response to Refugees," International Migration Review 15, nos. 1-2 (1981): 116-17; see also Girard, "Designated Classes."

19 UNHCR, "The 1951 Convention Relating to the Status of Refugees and Its 1967 Protocol" (Geneva: United Nations High Commission for Refugees, 2011), 3, http://www. unhcr.org/4ec262df9.html.

20 Basok and Simmons, "Review of the Politics of Canadian Refugee Selection," 148.

21 Lanphier, "Canada's Response to Refugees," 117.

22 Ibid., 129.

23 Gerald E. Dirks, Canada's Refugee Policy: Indifference or Opportunism? (Montreal and Kingston: McGill-Queen's University Press, 1977), 180.

24 Ibid.; see Whitaker, Double Standards.

25 Girard, "Designated Classes."

26 Ibid.

27 "Selection of Refugees for Resettlement in Canada," memorandum to Cabinet, 27 July 1970, Cabinet document 11032770, file 1032-70, vol. 6373, RG2, Library and Archives Canada (LAC).

28 Lanphier, "Canada's Response to Refugees," 117; Basok and Simmons, "Review of the Politics of Canadian Refugee Selection," 133 .

29 Bonaventure Rutinwa, "Prima Facie Status and Refugee Protection," New Issues in Refugee Research, UNHCR Working Paper 69 (2002), 1-3.
30 Proposal by executive director, Immigration, to the Canada Employment and Immigration Commission, "Extension and other minor adjustment of the Indochinese Designated Class Regulations, 2 October 1984, file 8005-21, LAC. Approved by the Commission 12 October 1984.

31 Memorandum by J. H. Taylor and L. H. Legault, legal advisor and assistant deputy minister for legal, consular, and immigration affairs, to secretary of state for external affairs, 30 May 1986, file 85-29-4-Indochina, part 1, LAC.

32 Indochinese Consultative Group Meeting, Ottawa, 7-8 April 1988, file 85-29-4-Indochina, part one, LAC.

33 Kristin Bergtora Sandvik, "A Legal History: The Emergence of the African Resettlement Candidate in International Refugee Management," International Journal of Refugee Law 22, no. 1 (2010): 29-30; see also Robinson, "Comprehensive Plan of Action."

34 Bonaventure, "Prima Facie Status and Refugee Protection," 1-2.

35 Sten A. Bronee, "The History of the Comprehensive Plan of Action," International Journal of Refugee Law 5, no. 4 (1993): 541.

36 Preparatory Meeting for the International Conference on Indochinese Refugees, Kuala Lumpur, 7-9 March 1989, file 85-29-4-Indochina, part 3, vol. 12498, LAC. At the top of this document it reads "March 9, 1989 The Canadian High Commission."

37 Ibid.

38 Nick Mulder, associate deputy minister/vice-chairman, memorandum to the minister, 10 April 1989, file 85-29-4-Indochina, part 3, vol. 12498, LAC.

39 Nick Mulder, memorandum to the immigration minister, 27 August 1990, file 8620-9, LAC.

40 Ibid.

41 Ibid.

42 Nick Mulder, Associate Deputy Minister/Vice-Chairman, Memorandum to the Minister, April 10, 1989. file 85-29-4Indochina, part 3, vol. 12498, LAC.

43 Nick Mulder to Nancy Hughes Anthony, deputy minister of privatization and regulatory affair, 16 November 1990, file 8620-9, Immigration, Refugees and Displaced Persons-General Designated Classes, LAC. The document also includes the "Regulatory Impact Analysis Statement."

44 Internal/confidential summary of "Tokyo ICG Meeting [Intergovernmental Consultations on the Indochinese Refugee Problem, Tokyo, 14-15 November 1988], 14 November Second Session," 15 November 1988, file 85-29-4-Indochina, part 2; International Conference on Indochinese Refugees, Geneva, 13 and 14 June 1989, file 85-29-4-Indochina, part 4, vol. 12498, LAC; "Basic Country Positions: Comprehensive Plan of Action," internal/confidential summary of "Tokyo ICG Meeting-November 14 Second Session," 15 November 1988; Barbara McDougall to John McDermid, Minister of State, 28 August 1990, file 8620-9, vol. 1992, Immigration, Refugees and Displaced Persons-General Designated Classes, LAC. 
45 UNHCR, Resettlement Handbook, 2011 ed. (Geneva: United Nations High Commission for Refugees, 2011), 49.

46 Indochinese Consultative Group Meeting, Ottawa, 7-8 April 1988, file 85-29-4-Indochina, part 1, LAC.

47 T. Alexander Aleinikoff, "State-Centered Refugee Law: From Resettlement to Containment," Michigan Journal of International Law 14, no. 1 (1992): 120-38; B. S. Chimni, "From Resettlement to Involuntary Repatriation: Towards a Critical History of Durable Solutions to Refugee Problems," Refugee Survey Quarterly 23, no. 3 (October 2004): 55-73; "The Geopolitics of Refugee Studies: A View from the South," Journal of Refugee Studies 11, no. 4 (1998): 350-74.

48 Chimni, "From Resettlement to Involuntary Repatriation," 58.

49 Andrew Shacknove, "From Asylum to Containment," International Journal of Refugee Law 5, no. 4 (1993), quoted in Jennifer Hyndman and Wenona Giles, "Waiting for What? The Feminization of Asylum in Protracted Situations," Gender, Place and Culture 18, no. 3 (June 2011): 362.

50 Aleinikoff, "State-Centered Refugee Law," 127.

51 Ibid., 134.

52 Jennifer Hyndman, "A Refugee Camp Conundrum: Geopolitics, Liberal Democracy, and Protracted Refugee Situations," Refuge 28, no. 2 (2011): 12.

53 UNHCR, Resettlement Handbook, 49; Shauna Labman, "Resettlement's Renaissance: A Cautionary Advocacy," Refuge 24, no. 2 (2007): 36; Sandvik, "Legal History," 21. Sandvik suggests that resettlement became the least-preferred durable solution as early as the mid-1980s.

54 David A. Martin, "Chapter vi: The Role of the Office of the un High Commissioner for Refugees," The United States Refugee Admissions Program: Reforms for a New Era of Refugee Resettlement (Migration Policy Institute and the Bertelsman, 8 July 2004), http://2001-2009.state.gov/g/ $\mathrm{prm} / \mathrm{refadm} / \mathrm{rls} / \mathrm{rpts} / 36066 . \mathrm{htm}$.

55 Ibid.,

56 Sandvik, "Legal History," 42-3.

57 Ibid., 43.

58 Ibid.

59 UNHCR, personal interview with author, 5 June 2012.

60 Martin, "Role of the Office of the un High Commissioner for Refugees."

61 See Labman, "Resettlement's Renaissance."

62 UNHCR, Convention Plus Core Group on the Strategic Use of Resettlement, Multilateral Framework of Understandings on Resettlement (Geneva: UNHCR, 21 June 2004); Agenda for Protection, 3rd. ed. (Geneva: UNHCR, October 2003).

63 UNHCR, Resettlement Handbook, 53; see also Martin, "Role of the Office of the un High Commissioner for Refugees."

64 UNHCR, Multilateral Framework of Understanding on Resettlement (Geneva: UNHCR, High Commissioner's Forum, 16 September 2004).

65 Ibid.
66 See UNHCR, Position Paper on the Strategic Use of Resettlement (Geneva: Annual Tripartite Consultations on Resettlement, 6-8 July 2010).

67 Shauna Labman, "At Law's Border: Unsettling Refugee Resettlement" (PhD diss., University of British Columbia, 2012), 109.

68 UNHCR, personal interview with author, 5 June 2012.

69 Joanne Van Selm, "The Strategic Use of Resettlement: Changing the Face of Protection?," Refuge 22, no. 1 (2004): 46.

70 Ibid

71 UNHCR, personal interview with author, 23 June 2011.

72 UNHCR, personal interview with author, 5 June 2012.

73 Anna Pratt, Securing Borders: Detentions and Deportation in Canada (Vancouver: UBC Press, 2005).

74 Casasola, "Current Trends and New Challenges," 81.

75 Mariana Valverde and Michael S. Mopas, "Insecurity and the Dream of Targeted Governance," in Global Governmentality: Governing International Spaces, ed. William Walters and Wendy Larner, 233-50 (London: Routledge, 2004).

76 Shauna Labman explains, "To overcome the legislative requirement for individual refugee assessments, the Minister's discretion in section 25 of IRPA to grant an exemption from the Act was used to declare the Sudanese and Somalis as prima facie refugees and vulnerable. This permitted CIC to use a singular claim for each group and exempted the refugees from the 'ability to establish' requirement." Labman, At Law's Border, 219.

77 CBSA, personal interview with author, 6 October 2011

78 Ibid.

79 Ibid.

8 o Ibid.

81 Ibid.

82 CIC, personal interview with author, 21 July 2011.

83 Ibid.

84 Ibid.

85 СBSA, personal interview, 6 October 2011.

86 I encountered the expression "generating efficiencies" in several interviews with officials from CIC, CBSA, and DFAIT.

87 CIC, personal interview with author, 21 July 2011.

88 Ibid.

89 CBSA, personal interview, 3 November 2011.

90 Groups of special humanitarian concern identified by the Us refugee program

91 UNHCR, Resettlement Handbook, 233-4.

92 Ibid., 233-41; ibid. (2004 ed.), chap. 7; UnHCR, Group Profile and Proposal Document, Bhutanese Refugees in Nepal for Group Resettlement Referral to the United States (6 June 2007); unHCR, Group Profile \& Proposal Document, Myanmar Refugees in Mae La Oon Camp, Thailand (April 2006).

93 Martin, "Role of the Office of the Un High Commissioner for Refugees."

94 Ibid. 
95 UNHCR, personal interview with author, 28 August 2012. 96 Ibid.

97 CCR, personal interview with the author, 2 August 2012; see also Labman, At Law's Border, 218.

98 UNHCR, personal interview with author, 5 June 2012.

99 Jennifer Hyndman, Managing Displacement: Refugees and the Politics of Humanitarianism (Minneapolis: University of Minnesota Press, 2000), 117-47.
100 UNHCR, personal interview with author, 28 August 2012.

Robert C. Batarseh is a PhD candidate in the Political Science program at York University. The author may be contacted at robertbatarseh@gmail.com.

(C) Robert C. Batarseh, 2016. This open-access work is licensed under a Creative Commons Attribution-NonCommercial 4.0 International License, which permits use, reproduction and distribution in any medium for non-commercial purposes, provided the original author(s) are credited and the original publication in Refuge: Canada's Journal on Refugees is cited. 